\title{
APLIKASI KEAMANAN DOCUMENT DIGITAL MENGGUNAKAN ALGORITMA STEGANOGRAFI DISCRETE COSINE TRANSFORM (DCT) PADA PERUSAHAN ALAT BERAT
}

\author{
Muhammad Kailani Ridwan'; William Frado Pattipeilohy²; Sanwani3 \\ ${ }^{*}$ Corespondent Author \\ Sistem Informasi ${ }^{1,2}$ \\ Universitas Budi Luhur 1,2 \\ www.budiluhur.ac.id ${ }^{1,2}$ \\ kheys.ridwan@gmail.com ${ }^{1}$,william_frado@budiluhur.ac.id ${ }^{2}$ \\ Sistem Informasi ${ }^{3}$ \\ STMIK Nusa Mandiri 3 \\ www.nusamandiri.ac.id ${ }^{3}$ \\ sanwani.swq@nusamandiri.ac.id ${ }^{3}$
}

\begin{abstract}
Electronic documents are information that is permitted or stored in a way that is requested by a computer or other electronic device to be installed, assigned or processed. These documents consist of text, graphics or spreadsheets. For the current technological developments that improve progress, security is very important in companies that are difficult to avoid the follow-up of information by parties who are not responsible. One method that can be used to obtain digital documents is using Steganography and Cryptography technology by using Discrete Cosine Transform (DCT) technology and Advanced Desktop Encryption Standard (AES-192) algorithm based on Java Desktop. The purpose of this application is to prepare data or files to be hidden on the cover image of the file. Before inserting with the closing image file, the file is encrypted with a symmetrical key using the AES-192 algorithm. The benefits obtained in this application, the confidentiality of information or data on this heavy equipment company can be difficult with good and safe. With this application it is expected to help the confidentiality of information or data on heavy equipment companies. .
\end{abstract}

Keywords: Steganografi, Discrete Cosine Transform, DCT, Kriptografi, AES-192, Advanced Encryption Standard.

Intisari-Dokumen elektronik adalah informasi yang direkam atau disimpan dengan cara yang memerlukan perangkat komputer atau perangkat elektronik lain untuk menampilkan ,menafsirkan atau memprosesnya. Dokumen-dokumen tersebut berupa teks, grafik atau spreadsheet. Seiring perkembangan teknologi saat ini yang semakin maju, keamanan menjadi sangat penting pada perusahaan alat berat untuk menghindari terjadinya tindak pencurian informasi oleh pihakpihak yang tidak bertanggung jawab. Salah satu cara yang dapat digunakan untuk mengamankan dokumen digital adalah memanfaatkan teknologi Steganografi dan Kriptografi dengan menggunakan algoritma Discrete Cosine Transform (DCT) dan algoritma Advanced Encryption Standard (AES-192) berbasis Java Dekstop. Tujuan aplikasi ini mengamankan sebuah data atau file yang akan disembunyikan pada file image cover. Sebelum disisipkan dengan file image cover, file tersebut dilakukan proses enkripsi pesan text terlebih dahulu dengan kunci simetris menggunakan algoritma AES192. Manfaat yang didapatkan dalam aplikasi ini, kerahasiaan informasi atau data pada perusahfaan alat berat tersebut bisa terjaga dengan baik dan aman. Dengan aplikasi ini diharapkan dapat membantu menjaga kerahasiaan informasi atau data pada perusahaan alat berat.

Kata Kunci: Steganografi, Discrete Cosine Transform, DCT, Kriptografi, AES-192, Advanced Encryption Standard.

\section{PENDAHULUAN}

Dalam era globalisasi perkembangan teknologi yang semakin pesat telah mempengaruhi segala bidang untuk terus berusaha membuat sistem informasi yang lebih baik. Salah satu kunci keberhasilan untuk menghadapi persaingan global adalah dengan terus meningkatkan pengetahuan yang dimiliki oleh setiap pribadi dalam menciptakan suatu sistem yang dapat berguna sesuai dengan keperluan masing-masing individu(Latif \& Pratama, 2015). Sehingga dapat menghantarkan dan mendapatkan informasi lebih cepat dibandingkan dengan teknologi yang 
digunakan sebelumnya, karena banyak pekerjaan dapat diselesaikan dengan cepat, akurat, dan efisien(Yuniati, Indriyanta, \& Rachmat C., 2011) .

Salah satu dampak negative dalam perkembangan teknologi adalah adanya pencurian data, yang merupakan salah satu masalah serius dan ditakuti oleh para pengguna jaringan komunikasi di Alat Berat(Nurdin Bagenda \& Mulyana, 2016). Dengan adanya pencurian data maka aspek keamanan dalam pertukaran informasi serta penyimpanan data dianggap penting(Hasugian, 2013) pada perusahan alat berat, karena suatu komunikasi data jarak jauh, belum tentu memiliki jalur transmisi yang aman dari penyadapan, serta penyimpanan data belum tentu aman dari pencurian(Nurdin, 2017), sehingga keamanan informasi menjadi bagian penting dalam dunia informasi itu sendiri. Salah satunya untuk mengamankan suatu informasi tersebut dengan menggunakan metode steganografi dan kriptografi(Anggraini \& Sakti, 2014).

Metode Algoritma steganografi yang digunakan yaitu Algoritma Discrete Cosine Transform (DCT) dan metode kriptografi yang digunakan adalah Algoritma Advanced Encryption Standard (AES-192). Media Steganografi sebagai cover object adalah file berupa citra digital image (*.jpg,*.jpeg,*.bmp, *.png). Menyembunyikan pesan file document $\left({ }^{*}\right.$.docx, ${ }^{*}$.doc, ${ }^{*}$ xls, ${ }^{*}$.xlsx dan pdf) ukuran file hanya dibatasi $1 \mathrm{MB}$ dan tidak melebihi ukuran file Cover Image. Mekanisme penentuan file yang ingin di-encode dan di-decode hanya berdasarkan exstensi file (format file).

Dengan penggunaan aplikasi ini akan memperkuat system keamanan document sehingga perusahaan memiliki rasa ketenangan di bidang keamanan data dan mampu menjalankan bisnis nya dengan baik serta mampu mengembangkan bisnis dibidang yang lain.

\section{BAHAN DAN METODE}

Metode yang digunakan dalam penelitian ini adalah dengan melakukan metode penelitian kepustakaan, wawancara dan observasi di perusahaan alat berat. Pada metode pengembangan sistem yang digunakan adalah dengan tahap antara lain analisis, desain, implementasi dan perawatan.

Steganografi merupakan suatu ilmu atau seni dalam menyembunyikan informasi dengan memasukkan informasi tersebut ke dalam pesan lain(Niswati, 2012). Dengan demikian keberadaan informasi tersebut tidak diketahui oleh orang lain. Tujuan dari steganografi adalah untuk menyembunyikan pesan dalam pesan berbahaya lainnya dengan cara yang tidak memungkinkan musuh apapun bahkan untuk mendeteksi bahwa ada pesan kedua. Secara umum, teknik steganografi yang baik harus memiliki visual/imperceptibility statistik yang baik dan payload yang cukup(Alatas, 2009). Steganografi membutuhkan dua aspek yaitu media penyimpan dan informasi rahasia yang akan disembunyikan. Metode steganografi sangat berguna jika digunakan pada steganografi komputer karena banyak format file digital yang dapat dijadikan media untuk menyembunyikan pesan. Steganografi digital menggunakan media digital sebagai wadah penampung, misalnya teks, citra, suara, dan video. Data rahasia yang disembunyikan juga dapat berupa teks, citra, suara, atau video.

Discrete Cosine Transform (DCT) adalah digunakan untuk mengubah sebuah sinyal menjadi komponen frekuensi dasarnya. Discrete Cosine Transform(DCT) termasuk metode steganography pada Algorithms and Transformation yang menyembunyikan data dalam fungsi matematika(Obukhov \& Kharlamov, 2008). DCT mempunyai dua sifat utama untuk kompresi citra dan video yaitu Mengkonsentrasikan energi citra ke dalam sejumlah kecil koefisien (energi compaction). Meminimalkan saling ketergantungan diantara koefisien-koefisien (decorrelation).

Standar enkripsi dengan kunci-simetris yang diadopsi oleh pemerintah Amerika Serikat terdiri atas 3 blok cipher, yaitu AES-128, AES-192 dan AES-256, yang diadopsi dari koleksi yang lebih besar yang awalnya diterbitkan sebagai Rijndael. Masing-masing cipher memiliki ukuran 128-bit, dengan ukuran kunci masing-masing 128, 192, dan 256 bit. AES telah dianalisis secara luas dan sekarang digunakan di seluruh dunia, seperti halnya dengan pendahulunya, Data Encryption Standard (DES)(Rahman, Miah, \& Azad, 2014).

Setiap 3 blok chiper pada AES-128, AES-192 dan AES-256 mempunyai perbedaan pada jumlah key dan jumlah putaran keterangan pada tabel 2 .

Tabel 1 : Perbandingan Jumlah Round dan Key pada Tipe AES

\begin{tabular}{cccc}
\hline Tipe & $\begin{array}{c}\text { Jumlah } \\
\text { Key } \\
\text { (NK) }\end{array}$ & $\begin{array}{c}\text { Ukuran } \\
\text { Blok } \\
\text { (Nb) }\end{array}$ & $\begin{array}{c}\text { Jumlah } \\
\text { Putaran } \\
\text { (Nr) }\end{array}$ \\
\hline AES-128 & 4 & 4 & 10 \\
\hline AES-192 & 6 & 4 & 12 \\
\hline AES-256 & 8 & 4 & 14 \\
\hline
\end{tabular}

Sumber : (Bouillaguet et al., 2012)

Pada dasarnya, operasi Advanced Encryption Standard (AES) dilakukan terhadap Array of Byte 
dua dimensi yang disebut State. State mempunyai ukuran NROWS x NCOLS. Pada awal enkripsi, data masukan yang berupa in 0 , in2, in 4 ,in5, in6, in7, in8, in9, in10, in11, in12, in13, in14, in15 disalin ke dalam Array State.

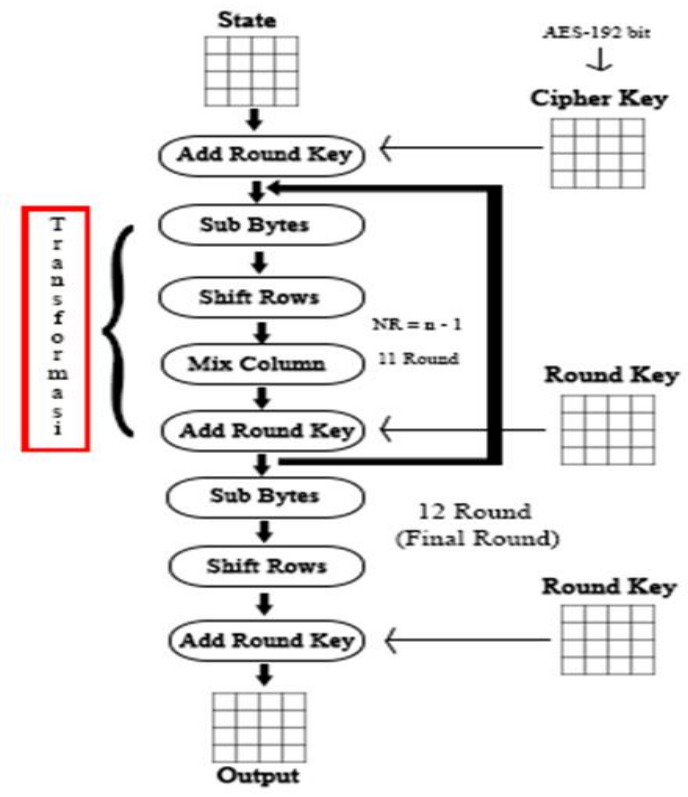

Sumber : (Primartha, 2013)

Gambar 1. Proses Enkripsi AES - 192

Proses Enkripsi pada gambar 1 dimulai dari AddRoundKey. AddRoundKey yaitu mengkobinasikan sebuah Chiperkey dan State dengan menggunakan operator XOR(Saputra \& Kusumaningsih, 2018). Yang kedua Sub Bytes adalah menukar isi matriks dengan baris dan kolom pada tabel S-Box. Di bawah ini adalah contoh tabel S-Box. Yang ke tiga Shift Rows adalah sebuah proses melakukan pergeseran pada setiap elemen blok/tabel yang dilakukan per barisnya. baris pertama tidak dilakukan pergeseran, baris kedua dilakukan pergeseran 1 byte, baris ketiga dilakukan pergeseran 2 byte dan baris ke-empat dilakukan pergeseran 3 bytes. Berikutnya Mix Column adalah mengalikan tiap elemen dari Blok Chiper dengan matriks yang sudah ditentukan. Pengalian dilakukan seperti perkalian matriks biasa yaitu menggunakan Dot Product lalu perkalian keduanya dimasukkan ke dalam sebuah Blok Chiper baru. Bila sudah dikalikan semua dengan matriks yang sudah ditentukan. Maka terbentuk hasil Polynomial dengan bentuk biner dan hasil itu di gabungkan dengan rumus perkalian Mix Column pada setiap tahap perkalian matriks.

Dan yang terakhir Add Round Key adalah mengkombinasikan Chiperteks yang sudah ada dengan Chiperkey dihubungkan pada operator XOR(Hakim, Khairil, \& Utami, 2014).

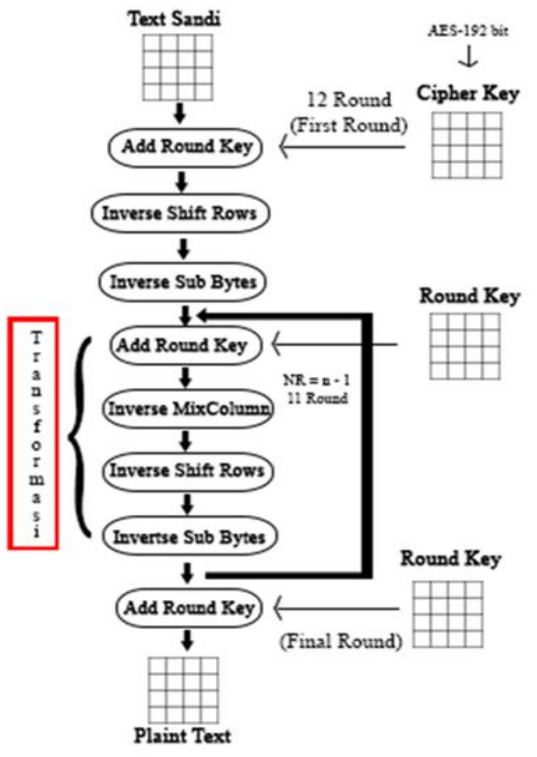

Sumber : (Primartha, 2013)

Gambar 2. Proses Deskrip AES - 192

Proses Deskrip pada gambar 2 dimulai dari InvMixColumns yaitu Setiap kolom dalam state dikalikan dengan matrik yang sudah ditentukan pada perkalian dalam AES-192, berikutnya InvShiftRows adalah transformasi byte yang berkebalikan dengan transformasi ShiftRows. Pada transformasi InvShiftRows, dilakukan pergeseran bit ke kanan sedangkan pada ShiftRows dilakukan pergeseran bit ke kiri. Yang ketiga InvSubBytes juga merupakan transformasi bytes yang berkebalikan dengan transformasi SubBytes. Pada InvSubBytes, tiap elemen pada state dipetakan dengan menggunakan tabel Inverse SBox dan yang terakhir AddRoundKey adalah mengkombinasikan chiperteks yang sudah ada dengan chiperkey dihubungkan pada operator XOR.

\section{HASIL DAN PEMBAHASAN}

Perancangan akan dibuat dua tampilan ata desain yaitu tampilan layar Embed dan tampilan layar Extract. Pada rancangan embedded gambar 3 dibawah dijelaskan tentang bagaimana user melakukan sebuah penyisipan pada file rahasia dengan file cover sehingga dapat menghasil stego image atau output gambar. Saat melakukan proses user diminta untuk memasukan password sepanjang 8 character dan akan dilakukan sebuah proses enkripsi yaitu AES-192. setelah selesai melakukan proses enkripsi akan disisipkan dengan menggunakan Discrete Cosine Transform. 


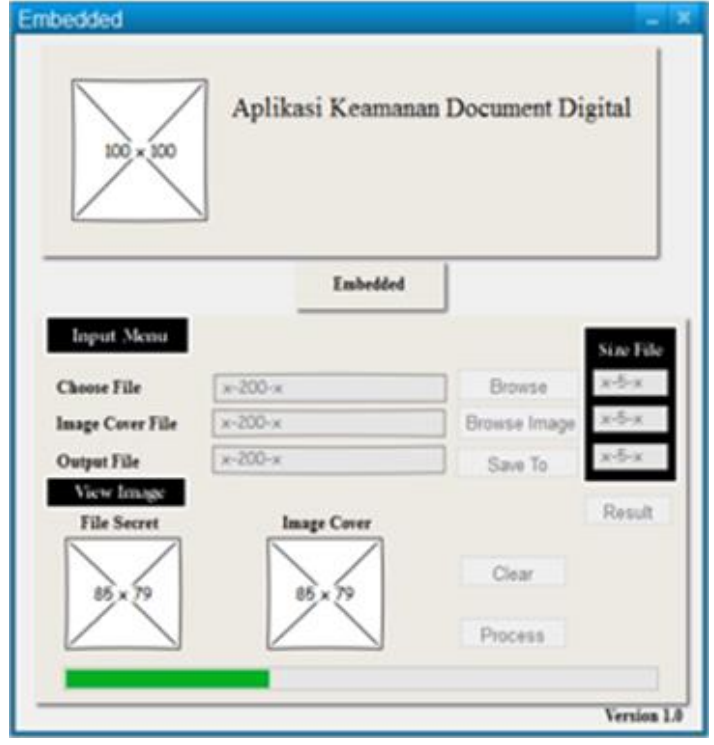

Sumber : (Sukarno, 2013)

Gambar 3. Rancangan Layar Embed

Setelah penjelasan dari rancangan layar porses embedded. Gambar 4 adalah gambar dari rancangan layar extract.

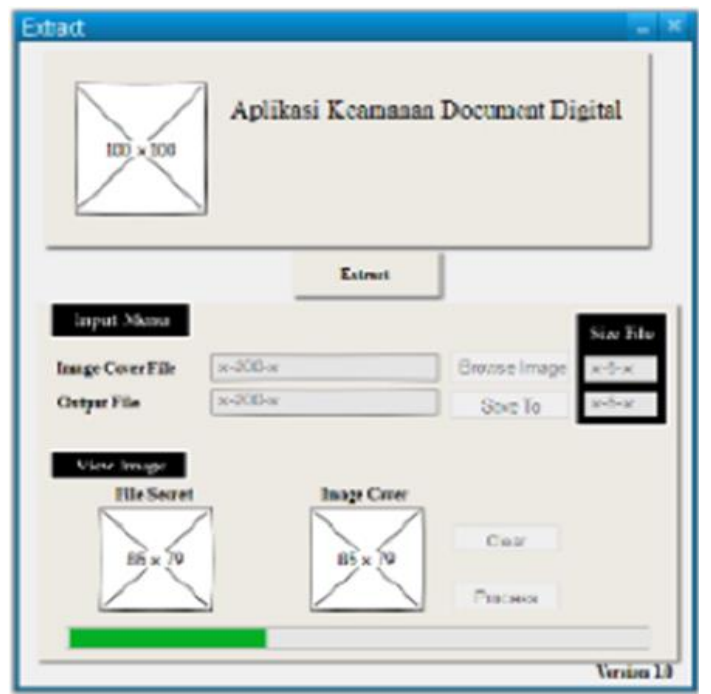

Sumber : (Sukarno, 2013)

Gambar 4. Rancangan Layar Extract

Pada rancangan layar form extract hampir sama dengan racangan layar embedded hanya saja ada beberapa perbedaan seperti tidak adanya choose file secret dikarenakan hanya mengeluarkan file asli dari stego image.

implementasi dan uji coba dari sistem yang akan dibuat. Bab ini akan menjelaskan tentang hasil dari proses embed dan extract berdasarkan uji yang telah disiapkan dengan berbagai uji coba file Cover dengan file document pada algoritma kripstografi AES-192 dan algoritma steganografi Discrete Cosine Transform (DCT). Pada bab ini juga akan membuat suatu evaluasi dari pengujian program tersebut. Evaluasi tersebut bertujuan agar selanjutnya progam ini akan dikembangkan kembali menjadi lebih baik lagi dan lebih berguna bagi yang menggunakan atau user. Tabel 2 menunjukani proses pengujian dari sample gambar atau file Cover.

Tabel 2 : Sample File Cover

\begin{tabular}{|c|c|c|c|c|}
\hline NO & Gambar Cover & $\begin{array}{c}\text { Nama } \\
\text { File }\end{array}$ & $\begin{array}{c}\text { Ukuran } \\
\text { Pixel }\end{array}$ & $\begin{array}{l}\text { Ukuran } \\
\text { Gambar }\end{array}$ \\
\hline 1 & & $\begin{array}{l}\text { Sample } \\
\text { 1.JPEG }\end{array}$ & $\begin{array}{c}1920 \mathrm{x} \\
1200\end{array}$ & $180 \mathrm{~KB}$ \\
\hline 2 & & $\begin{array}{l}\text { Sample } \\
\text { 2.JPG }\end{array}$ & $\begin{array}{c}2880 \mathrm{x} \\
1800\end{array}$ & $699 \mathrm{~KB}$ \\
\hline 3 & & $\begin{array}{l}\text { Sample } \\
\text { 3.JPG }\end{array}$ & $\begin{array}{c}640 x \\
640\end{array}$ & $128 \mathrm{~KB}$ \\
\hline 4 & & $\begin{array}{l}\text { Sample } \\
\text { 4.JPG }\end{array}$ & $\begin{array}{c}640 x \\
640\end{array}$ & $104 \mathrm{~KB}$ \\
\hline
\end{tabular}

Sumber : (Ridwan, 2019)

Pada sampel tabel 2 menggunakan 4 sampel file cover dengan masing-masing ukuran pixel tinggi dan lebar yang berbeda-beda berekstensi tipe file jpg. Kemudian sampel file cover diatas akan dilakukan uji coba untuk melakukan penyisipan pada file dokumen $p d f$, xlsx dan docx dengan file cover sebagai media penampung. Dalam pengujian kali ini akan dibahas antara proses embed dan extract antara file document. Tabel 3 adalah hasil uji coba pada percobaan file dokumen pada file cover.

Tabel 3: Pengujian Embed file docx,xlsx dan pdf

\begin{tabular}{|c|c|c|c|c|c|}
\hline \multirow[b]{2}{*}{ No } & \multicolumn{2}{|c|}{ File Secret } & \multicolumn{2}{|c|}{ File Gambar } & \multirow{2}{*}{$\begin{array}{c}\text { Waktu } \\
\text { Embed } \\
\text { (Sec.) }\end{array}$} \\
\hline & Nama File & Ukuran & $\begin{array}{l}\text { Nama } \\
\text { File }\end{array}$ & Ukuran & \\
\hline 1 & $\begin{array}{l}\text { smo 1-30 } \\
\text { des.docx }\end{array}$ & $28 \mathrm{~KB}$ & $\begin{array}{l}\text { Sample } \\
\text { 1.jpeg }\end{array}$ & $179 \mathrm{~KB}$ & 199.09 \\
\hline 2 & $\begin{array}{l}\text { smo 1-30 } \\
\text { des.docx }\end{array}$ & $28 \mathrm{~KB}$ & $\begin{array}{c}\text { Sample } \\
\text { 2.jpg }\end{array}$ & 699 KB & 245.23 \\
\hline 3 & $\begin{array}{l}\text { smo 1-30 } \\
\text { des.docx }\end{array}$ & $28 \mathrm{~KB}$ & $\begin{array}{l}\text { Sample } \\
\text { 3.jpg }\end{array}$ & $128 \mathrm{~KB}$ & 155.33 \\
\hline 4 & $\begin{array}{c}\text { smo 1-30 } \\
\text { des.docx }\end{array}$ & $28 \mathrm{~KB}$ & $\begin{array}{c}\text { Sample } \\
\text { 4.jpg }\end{array}$ & $104 \mathrm{~KB}$ & 156.09 \\
\hline 5 & $\begin{array}{c}\text { Master 1-30 } \\
\text { TARAKAN SEPT } \\
\text { 2015.xlsx } \\
\end{array}$ & $22 \mathrm{~KB}$ & $\begin{array}{l}\text { Sample } \\
\text { 1.jpeg }\end{array}$ & $179 \mathrm{~KB}$ & 136.91 \\
\hline 6 & $\begin{array}{c}\text { Master } 1-30 \\
\text { TARAKAN SEPT }\end{array}$ & $22 \mathrm{~KB}$ & $\begin{array}{l}\text { Sample } \\
\text { 2.jpg }\end{array}$ & $699 \mathrm{~KB}$ & 198.58 \\
\hline
\end{tabular}




\begin{tabular}{|c|c|c|c|c|c|}
\hline \multicolumn{3}{|c|}{ 2015.xlsx } & & & \\
\hline 7 & $\begin{array}{c}\text { Master } 1-30 \\
\text { TARAKAN SEPT } \\
\text { 2015.xlsx } \\
\end{array}$ & $22 \mathrm{~KB}$ & $\begin{array}{c}\text { Sample } \\
\text { 3.jpg }\end{array}$ & $128 \mathrm{~KB}$ & 96.65 \\
\hline 8 & $\begin{array}{c}\text { Master } 1-30 \\
\text { TARAKAN SEPT } \\
\text { 2015.xlsx } \\
\end{array}$ & $22 \mathrm{~KB}$ & $\begin{array}{c}\text { Sample } \\
\text { 4.jpg }\end{array}$ & $104 \mathrm{~KB}$ & 95.14 \\
\hline 9 & $\begin{array}{c}\text { CORPORATE } \\
\text { SECRETARY.pdf }\end{array}$ & $17 \mathrm{~KB}$ & $\begin{array}{c}\text { Sample } \\
\text { 1.jpeg }\end{array}$ & $179 \mathrm{~KB}$ & 34.51 \\
\hline 10 & $\begin{array}{c}\text { CORPORATE } \\
\text { SECRETARY.pdf }\end{array}$ & $17 \mathrm{~KB}$ & $\begin{array}{c}\text { Sample } \\
\text { 2.jpg }\end{array}$ & $699 \mathrm{~KB}$ & 77.22 \\
\hline 11 & $\begin{array}{c}\text { CORPORATE } \\
\text { SECRETARY.pdf }\end{array}$ & $17 \mathrm{~KB}$ & $\begin{array}{c}\text { Sample } \\
\text { 3.jpg }\end{array}$ & $128 \mathrm{~KB}$ & 11.70 \\
\hline 12 & $\begin{array}{c}\text { CORPORATE } \\
\text { SECRETARY.pdf }\end{array}$ & $17 \mathrm{~KB}$ & $\begin{array}{c}\text { Sample } \\
\text { 4.jpg }\end{array}$ & $104 \mathrm{~KB}$ & 12.28 \\
\hline
\end{tabular}

Sumber : (Ridwan, 2019)

Pada hasil pengujian embed dapat dilihat pada tabel 4 menggunakan sebuah PSNR dan MSE.

Tabel 4 : Hasil Pengujian Embed

\begin{tabular}{|c|c|c|c|c|c|}
\hline \multirow[b]{2}{*}{ No } & \multirow[t]{2}{*}{ Format } & \multicolumn{2}{|c|}{ Stego File } & \multirow{2}{*}{$\begin{array}{l}\text { PSNR } \\
\text { (db) }\end{array}$} & \multirow{2}{*}{$\begin{array}{l}\text { MSE } \\
\text { (db) }\end{array}$} \\
\hline & & $\begin{array}{c}\text { Nama } \\
\text { File }\end{array}$ & Ukuran & & \\
\hline 1. & Doc & $\begin{array}{l}\text { Stego } \\
\text { Gambar } \\
\text { 1.Jpeg }\end{array}$ & $1.33 \mathrm{MB}$ & 50.3366 & 0.6018 \\
\hline 2 & Doc & $\begin{array}{c}\text { Stego } \\
\text { Gambar } \\
\text { 2.JPG }\end{array}$ & $7.57 \mathrm{MB}$ & 53.3827 & 0.2984 \\
\hline 3 & Doc & $\begin{array}{c}\text { Stego } \\
\text { Gambar } \\
\text { 3.JPG }\end{array}$ & 885 KB & 43.7495 & 2.7424 \\
\hline 4 & Doc & $\begin{array}{c}\text { Stego } \\
\text { Gambar } \\
\text { 4.JPG }\end{array}$ & 813 KB & 43.1658 & 3.1369 \\
\hline 5 & Xlsx & $\begin{array}{c}\text { Stego } \\
\text { Gambar } \\
\text { 1.Jpeg }\end{array}$ & $1.31 \mathrm{MB}$ & 51.0571 & 0.5098 \\
\hline 6 & Xlsx & $\begin{array}{c}\text { Stego } \\
\text { Gambar } \\
\text { 2.JPG }\end{array}$ & $7.56 \mathrm{MB}$ & 53.8033 & 0.2709 \\
\hline 7 & Xlsx & $\begin{array}{c}\text { Stego } \\
\text { Gambar } \\
\text { 3.JPG }\end{array}$ & 878 KB & 44.6986 & 2.2041 \\
\hline 8 & Xlsx & $\begin{array}{c}\text { Stego } \\
\text { Gambar } \\
\text { 4.JPG }\end{array}$ & 803 KB & 44.1296 & 2.5126 \\
\hline 9 & Pdf & $\begin{array}{c}\text { Stego } \\
\text { Gambar } \\
\text { 1.Jpeg }\end{array}$ & $1.29 \mathrm{MB}$ & 51.8329 & 0.4264 \\
\hline 10 & Pdf & $\begin{array}{c}\text { Stego } \\
\text { Gambar } \\
\text { 2.JPG }\end{array}$ & $7.55 \mathrm{MB}$ & 54.2310 & 0.2455 \\
\hline 11 & Pdf & $\begin{array}{c}\text { Stego } \\
\text { Gambar } \\
\text { 3.JPG }\end{array}$ & 874 KB & 45.7243 & 1.7404 \\
\hline 12 & Pdf & $\begin{array}{c}\text { Stego } \\
\text { Gambar } \\
\text { 4.JPG }\end{array}$ & 794 KB & 45.1793 & 1.9731 \\
\hline & TOTAL & & & 581.290 & 16.662 \\
\hline
\end{tabular}

Sumber : (Ridwan, 2019)

Hasil pengujian dari tabel 4 pada saat selesai melakukan embed dapat ditarik kesimpulan bahwa rata-rata PSNR $\frac{581.2907}{12}=48.4409 \mathrm{db}$ dan MSE $\frac{16.6623}{12}=1.3885 \mathrm{db}$ kualitas citra yang dilakukan penyisipan adalah baik dengan rata-rata $>40 \mathrm{db}$ dari 12 sample dari tipe file dokumen yang berbeda-beda.

Tabel 5 : Hasil Pengujian Extract

\begin{tabular}{|c|c|c|c|c|c|}
\hline \multirow[b]{2}{*}{$\begin{array}{l}\mathbf{N} \\
\mathbf{o}\end{array}$} & \multicolumn{2}{|c|}{ Stego File } & \multirow[b]{2}{*}{ Hasil Extract } & \multirow[b]{2}{*}{ Ukuran } & \multirow{2}{*}{$\begin{array}{c}\text { Waktu } \\
\text { (Seconds) }\end{array}$} \\
\hline & $\begin{array}{l}\text { Nama } \\
\text { File }\end{array}$ & Ukuran & & & \\
\hline 1 & $\begin{array}{c}\text { Stego } \\
\text { Gambar } \\
\text { 1.Jpeg }\end{array}$ & $\begin{array}{l}1.33 \\
\mathrm{MB}\end{array}$ & $\begin{array}{l}\text { smo } 1-30 \\
\text { des.docx }\end{array}$ & $28 \mathrm{~KB}$ & 44.25 \\
\hline 2 & $\begin{array}{c}\text { Stego } \\
\text { Gambar } \\
\text { 2.JPG }\end{array}$ & $\begin{array}{c}7.57 \\
\mathrm{MB}\end{array}$ & $\begin{array}{l}\text { smo } 1-30 \\
\text { des.docx }\end{array}$ & $28 \mathrm{~KB}$ & 94.91 \\
\hline 3 & $\begin{array}{c}\text { Stego } \\
\text { Gambar } \\
\text { 3.JPG }\end{array}$ & $885 \mathrm{~KB}$ & $\begin{array}{l}\text { smo } 1-30 \\
\text { des.docx }\end{array}$ & $28 \mathrm{~KB}$ & 16.08 \\
\hline 4 & $\begin{array}{c}\text { Stego } \\
\text { Gambar } \\
\text { 4.JPG }\end{array}$ & $813 \mathrm{~KB}$ & $\begin{array}{l}\text { smo 1-30 } \\
\text { des.docx }\end{array}$ & $28 \mathrm{~KB}$ & 15.40 \\
\hline 5 & $\begin{array}{c}\text { Stego } \\
\text { Gambar } \\
\text { 1.Jpeg }\end{array}$ & $\begin{array}{l}1.31 \\
\mathrm{MB}\end{array}$ & $\begin{array}{c}\text { Master 1-30 } \\
\text { TARAKAN SEPT } \\
\text { 2015.xlsx } \\
\end{array}$ & $22 \mathrm{~KB}$ & 34.51 \\
\hline 6 & $\begin{array}{c}\text { Stego } \\
\text { Gambar } \\
\text { 2.JPG } \\
\end{array}$ & $\begin{array}{c}7.56 \\
\mathrm{MB}\end{array}$ & $\begin{array}{c}\text { Master } 1-30 \\
\text { TARAKAN SEPT } \\
\text { 2015.xlsx } \\
\end{array}$ & $22 \mathrm{~KB}$ & 77.22 \\
\hline 7 & $\begin{array}{c}\text { Stego } \\
\text { Gambar } \\
\text { 3.JPG }\end{array}$ & $878 \mathrm{~KB}$ & $\begin{array}{c}\text { Master 1-30 } \\
\text { TARAKAN SEPT } \\
\text { 2015.xlsx }\end{array}$ & $22 \mathrm{~KB}$ & 11.70 \\
\hline 8 & $\begin{array}{c}\text { Stego } \\
\text { Gambar } \\
\text { 4.JPG }\end{array}$ & $803 \mathrm{~KB}$ & $\begin{array}{c}\text { Master } 1-30 \\
\text { TARAKAN SEPT } \\
\text { 2015.xlsx } \\
\end{array}$ & $22 \mathrm{~KB}$ & 12.28 \\
\hline 9 & $\begin{array}{c}\text { Stego } \\
\text { Gambar } \\
\text { 1.Jpeg }\end{array}$ & $\begin{array}{l}1.29 \\
\mathrm{MB}\end{array}$ & $\begin{array}{l}\text { CORPORATE } \\
\text { SECRETARY.pdf }\end{array}$ & $17 \mathrm{~KB}$ & 27.0 \\
\hline $\begin{array}{l}1 \\
0\end{array}$ & $\begin{array}{c}\text { Stego } \\
\text { Gambar } \\
\text { 2.JPG }\end{array}$ & $\begin{array}{c}7.55 \\
\text { MB }\end{array}$ & $\begin{array}{l}\text { CORPORATE } \\
\text { SECRETARY.pdf }\end{array}$ & $17 \mathrm{~KB}$ & 50.88 \\
\hline $\begin{array}{l}1 \\
1\end{array}$ & $\begin{array}{c}\text { Stego } \\
\text { Gambar } \\
\text { 3.JPG }\end{array}$ & $874 \mathrm{~KB}$ & $\begin{array}{l}\text { CORPORATE } \\
\text { SECRETARY.pdf }\end{array}$ & $17 \mathrm{~KB}$ & 7.77 \\
\hline $\begin{array}{l}1 \\
2\end{array}$ & $\begin{array}{c}\text { Stego } \\
\text { Gambar } \\
\text { 4.JPG } \\
\end{array}$ & $794 \mathrm{~KB}$ & $\begin{array}{l}\text { CORPORATE } \\
\text { SECRETARY.pdf }\end{array}$ & $17 \mathrm{~KB}$ & 8.61 \\
\hline
\end{tabular}

Sumber : (Ridwan, 2019)

Hasil pengujian diatas pada saat selesai melakukan extract. Dapat ditraik kesimpulan bahwa tidak terjadi perubahan size file yang diextract. Sehingga file tersebut sama seperti aslinya.

\section{KESIMPULAN}

Sesuai dengan pembahasan mengenai aplikasi keamanan document digital menggunakan algoritma steganografi discrete cosine transform (DCT) dan algoritma kriptografi advanced encryption standard (AES-192), maka kesimpulan yang dapat diambil antara lain yaitu yang pertama waktu yang digunakan untuk melakukan proses embed dan extract berbanding lurus dengan ukuran file yang diproses. Semakin besar ukuran file yang diproses maka semakin lama proses embed dan extract, semakin kecil ukuran file yang diproses, semakin cepat porses embed dan extract dilakukan. Kedua dengan adanya aplikasi steganografi dan kriptografi, proses penyimpan 
informasi menjadi lebih aman dan yang terakhir Proses extract dengan password yang asli akan mengembalikan file menjadi file semula tanpa mengalami perubahan sedikitpun. Penelitian ini masih jauh dari sempurna dan masih perlu banyak perbaikan dan pengembangan supaya menjadi lebih baik lagi. Adapun saran untuk pengembangan dari penelitian ini antara lain waktu proses embed dan extract file yang rata-rata berukuran besar diharapkan dapat berjalan lebih cepat pada hardware yang lebih baik, dikembangkan menggunakan algoritma steganograi yang lebih baik, agar ukuran file hasil embed diharapkan dapat menjadi lebih kecil lagi dan aplikasi ini diharapkan dapat ditingkatkan kinerjanya sehingga file cover tidak hanya file gambar png, jpg dan bmp saja, namun file cover lainnya serta dapat Juga file video dan audio.

\section{REFERENSI}

Alatas, P. (2009). Implementasi teknik steganografi dengan metode lsb pada citra digital. Universitas Gunadarma.

Anggraini, Y., \& Sakti, D. V. S. Y. (2014). Penerapan Steganografi Metode End of File (Eof) Dan Enkripsi Metode Data Encryption Standard ( Des ) Pada Aplikasi Pengamanan Data Gambar Berbasis Java. Konferensi Nasional Sistem Informasi, STMIK Dipanegara Makassar.

Bouillaguet, C., Derbez, P., Dunkelman, O., Fouque, P. A., Keller, N., \& Rijmen, V. (2012). Low-data complexity attacks on AES. IEEE Transactions on Information Theory. https://doi.org/10.1109/TIT.2012.2207880

Hakim, E. L., Khairil, \& Utami, F. H. (2014). Aplikasi Enkripsi Dan Deskripsi Data Menggunakan Algoritma Rc4 Dengan Menggunakan Bahasa Pemrograman Php. Jurnal Media Infotama.

Hasugian, A. H. (2013). Implementasi Algoritma Hill Cipher Dalam Penyandian Data. Pelita Informatika Budi Darma.

Latif, F., \& Pratama, A. W. (2015). Perancangan Sistem Informasi Manajemen Arsip Elektronik (E-Arsip) Berbasis Microsoft Access Pada PT.HI-TEST. Jurnal Akuntansi, Ekonomi Dan Manajemen Bisnis. https://doi.org/10.24843/LKJITI.6.3.16972

Niswati, Z. (2012). STEGANOGRAFI BERBASIS LEAST SIGNIFICANT BIT (LSB) UNTUK
MENYISIPKAN GAMBAR KE DALAM CITRA GAMBAR. Jurnal Lppm Unindra, 5. https://doi.org/http://dx.doi.org/10.30998/ faktorexacta.v5i2.194

Nurdin, A. P. N. (2017). Analisa Dan Implementasi Kriptografi Pada Pesan Rahasia. Jesik.

Nurdin Bagenda, D., \& Mulyana, I. (2016). PERANCANGAN SISTEM KEAMANAN BRANKAS MENGGUNAKAN KARTU RFID BERBASIS ARDUINO. JURNAL LPKIA.

Obukhov, A., \& Kharlamov, A. (2008). Discrete Cosine Transform for $8 x 8$ Blocks with CUDA. October.

Primartha, R. (2013). Penerapan Enkripsi dan Dekripsi File menggunakan Algoritma Advanced Encryption Standard (AES). Journal of Research in Computer Science and Applications.

Rahman, A. U., Miah, S. U., \& Azad, S. (2014). Advanced encryption standard. In Practical Cryptography: Algorithms and Implementations Using C++. https://doi.org/10.1201/b17707

Ridwan, M. (2019). APLIKASI KEAMANAN DOCUMENT DIGITAL MENGGUNAKAN ALGORITMA STEGANOGRAFI DISCRETE COSINE TRANSFORM (DCT) PADA PERUSAHAN ALAT BERAT. Jakarta.

Saputra, D., \& Kusumaningsih, D. (2018). Implementasi Keamanan Database Menggunakan Algoritma Aes-192 Pada Pt Gurita Lintas Samudera Berbasis Android. Jurnal Skanika, 1('Vol 1 No 3 (2018): Jurnal SKANIKA Juli 2018), 884-888. Retrieved from

http://jom.fti.budiluhur.ac.id/index.php/SKA NIKA/article/view/2501

Sukarno, A. S. (2013). Pengembangan Aplikasi Pengamanan Dokumen Digital Memanfaatkan Algoritma Advance Encryption Standard, RSA Digital Signature dan Invisible Watermarking. Prosiding Seminar Nasional Aplikasi Teknologi Informasi (SNATI) 2013.

Yuniati, V., Indriyanta, G., \& Rachmat C., A. (2011). ENKRIPSI DAN DEKRIPSI DENGAN ALGORITMA AES 256 UNTUK SEMUA JENIS FILE. Jurnal Informatika. https://doi.org/10.21460/inf.2009.51.69 